\title{
Erratum to: Sources of resistance to diseases of sugar beet in related Beta germplasm: I. Foliar diseases
}

\author{
M. C. Luterbacher • M. J. C. Asher • \\ E. DeAmbrogio $\cdot$ E. Biancardi · P. Stevanato • \\ L. Frese
}

Published online: 18 January 2013

(C) Springer Science+Business Media Dordrecht 2013

\section{Erratum to: Euphytica (2004) 139:105-121 DOI 10.1007/s10681-004-2488-5}

Due to an unfortunate turn of events, the fifth author's surname appeared incorrectly in the original publication and should have read Stevanato. The correct representation of the authors names is listed above and below and should be treated as definitive by the reader.

The online version of the original article can be found under doi:10.1007/s10681-004-2488-5.

M. C. Luterbacher · M. J. C. Asher ( $\square)$

Broom's Barn Research Station, Higham,

Bury St Edmunds, Suffolk IP28 6NP, UK

e-mail: mike.asher@bbsrc.ac.uk

E. DeAmbrogio

Società Produttori Sementi S.p.a. (SPSB), Galleria

del Reno 3, 40122 Bologna, Italy

E. Biancardi - P. Stevanato

Istituto Sperimentale per le Colture Industriali (ISCI),

Viale Amendola 82, 45100 Rovigo, Italy

L. Frese

Bundesanstalt für Züchtungsforschung an Kulturpflanzen

(BAZ) Gene Bank, Bundesallee 50, 38116 Braunschweig,

Germany 